\title{
Pengembangan video pembelajaran sinyal-sinyal wasit bola basket untuk guru penjasorkes sekolah menengah atas
}

\author{
Duwi Kurnianto Pambudi ${ }^{1}{ }^{*}$, S. Suharjana ${ }^{1}$ \\ ${ }^{1}$ Program Studi Ilmu Keolahragaan, Program Pascasarjana, Universitas Negeri Yogyakarta. \\ Jalan Colombo No. 1, Karangmalang, Yogyakarta, 55281, Indonesia \\ * Corresponding Author. Email: duwikurnianto@gmail.com \\ Received: 2 December 2016; Revised: 27 December 2017; Accepted: 20 April 2018
}

\begin{abstract}
Abstrak
Penelitian ini bertujuan untuk mengembangkan video pembelajaran sinyal-sinyal wasit sesuai dengan FIBA rules 2014 untuk Guru Penjasorkes SMA. Metode penelitian ini meliputi: (1)potensi dan masalah, (2) pengumpulan data, (3) desain produk, (4) validasi desain, (5) revisi desain, (6) ujicoba produk, (7) revisi produk, (8) ujicoba pemakaian, (9) revisi produk,(10) produksi masal. Subjek penelitian ini berjumlah 33 guru.Pengumpulan data menggunakan angket lembar penilaian produk dengan disertai lembar saran dan masukan untuk revisi produk.Analisis data menggunakan teknik analisis deskriptif dengan menggunakan persentase. Hasil penelitian adalah sebagai berikut: hasil validasi ahli media dan ahli materi menunjukkan nilai $88,58 \%$ dan berkategori sangat tinggi. Hasil ujicoba produk menunjukkan nilai $93,33 \%$ berkategori sangat tinggi. Hasil ujicoba pemakaian menunjukkan nilai $92,59 \%$, berkategori sangat tinggi. Hasil uji efektifitas/ uji operasional data pretest dan post test pada uji efektifitas/ uji operasional menunjukkan peningkatan rata-rata nilai sebesar $9,09 \%$ yaitu dari $74,24 \%$ pada saat pretest menjadi $818,33 \%$ pada saat post test.
\end{abstract}

Kata Kunci: video pembelajaran, sinyal-sinyal wasit, bola basket, guru SMA

\section{Developing learning video of basketball referee signals for physical education teachers in senior high school}

\begin{abstract}
This research aims to develop learning video of basketball refere signals based on FIBA Rules 2014 to physical education teacher of senior high school. This research method includes: (1) the potentials and problems, (2) data collection, (3) the design of the product, (4) design validation, (5) design revisions, (6) test products, (7) product revision, (8) user trial, (9) the revision of the product, (10) the mass production. Subjects of this study are 33 teachers. Collecting data using a questionnaire sheet product assessment, accompanied by pieces of advice and input for the revision of the product. Data analysis using descriptive analysis techniques using percentages. The results of the study are as follows: the results of validation media experts and subject matter experts demonstrate the value of $88.58 \%$ and a very high category. The trial results demonstrate the value of $93.33 \%$ product category is very high. User trial results demonstrate the value of $92.59 \%$, a very high category. The results of effectiveness test / operational test data is pretest and post-test on the effectiveness test / operational test showed an average increase in value by $9.09 \%$ from $74.24 \%$ at the time of the pretest be $818.33 \%$ at the post-test.
\end{abstract}

Keywords: learning video, the signals of the referee, basketball, senior high school teacher

How to Cite: Pambudi, D., \& Suharjana, S. (2018). Pengembangan video pembelajaran sinyal-sinyal wasit bola basket untuk guru penjasorkes sekolah menengah atas. Jurnal Keolahragaan, 6(1), 48-59. doi:http://dx.doi.org/10.21831/jk.v6i1.11880

dttp://dx.doi.org/10.21831/jk.v6i1.11880 


\section{PENDAHULUAN}

Pendidikan jasmani dan olahraga sebagai salah satu mata pelajaran wajib dalam kurikulum pendidikan menengah di Indonesia. Tujuan utama pembelajaran Pendidikan Jasmani Olahraga dan Kesehatan (Penjasorkes) di sekolah adalah untuk membantu agar peserta didik meningkatkan keterampilan geraknya.Tujuan utama lainnya juga agar mereka merasa senang dan terdorong berpartisipasi dalam berbagai bentuk aktivitas.

Keberhasilan tujuan pendidikan tidak bisa lepas dari situasi dan kondisi sekolah sangat berpengaruh terhadap kelancaran dan kesuksesan pembelajaran Penjasorkes di sekolah (Kusumawardana \& Sukadiyanto, 2013, p.121). Faktor lain keberhasilan pendidikan adalah faktor tenaga pendidik, pendidik adalah tenaga kependidikan yang berkualifikasi sebagai guru, dosen, konselor, pamong belajar, widyaiswara, tutor, instruktur, fasilitator, dan sebutan lain yang sesuai dengan kekhususannya, serta berpartisipasi dalam menyelenggarakan pendidikan, dalam sekolah dasar dan menengah pendidik disebut juga guru.

Guru Pendidikan Jasmani Olahraga dan kesehatan (Penjasorkes) adalah guru yang mengampu atau mengajarkan mata pelajaran olahraga pada sekolah baik sekolah dasar maupun sekolah menengah. Pendidikan jasmani dan olahraga merupakan salah satu mata pelajaran wajib pada sekolah dasar dan menengah sehingga dalam proses pembelajarannya selalu berkelanjutan dan berurutan sesuai dengan silabus pada kurikulum yang digunakan, sebagai guru olahraga seorang guru dituntut untuk setidaknya mengetahui berbagai jenis olahraga setidaknya olahraga yang ada di dalam silabus mata pelajaran sekolah menengah atas seperti: Permainan bola besar menggunakan permaian (sepakbola,bola voli, bola basket), permainan bola kecil menggunakan permainan (softball, bulu tangkis, tenis meja, atletik (lompat jauh, lompat tinggi), beladiri (pencaksilat), senam lantai dan masih banyak lagi mata pelajaran yang berkaitan dengan pendidikan jasmani olahraga dan kesehatan.

Bolabasket merupakan salah satu permainan bola besar dengan permainan yang diajarkan dalam silabus mata pelajaran penjasorkes untuk Sekolah menengah atas (SMA), bolabasket diajarkan kepada siswa SMA mulai dari kelas X (sepuluh), XI (Sebelas), XII (Dua belas), atau bisa dikatakan permainan bola basket diajarkan pada setiap tingkatan di SMA, sehingga sangat diperlukan pengetahuan yang cukup bagi seorang guru untuk mengajarkan materi bolabasket karena bolabasket mempunyai banyak hal yang harus diketahui seperti: (1) teknik dasar bolabasket (passing, driblling, shooting ), (2) pola permainan (menyerang dan bertahan), (3) peraturan permainan bolabasket. Peraturan bolabasket sendiri terdiri dari beberapa peraturan dasar yaitu menghentikan dan menjalankan waktu pertandingan, mencetak angka (dalam bolabasket keberhasilan mencetak poin 1,2,3 berdasarkan dari tempat mencetak angka), violation (penyimpangan atas peraturan) dan foul (penyimpangan dari peraturan mengenai persinggungan perorangan yang tidak sah dengan seorang lawan dan/atau perilaku yang tidak sportif), yang unik dalam peraturan bolabasket adalah setiap terjadinya violation dan foul mempunyai gerakan dan sinyal yang berbedabeda.

Organisasi yang menaungi bolabasket Internasional adalah FIBA (Federation Internationale de Basketball), didirikan pada tanggal 18 Juni 1932 berpusat di Jenewa Swiss. FIBA mengeluarkan peraturan yang mengatur mengenai permainan bola basket yang disebut FIBA Rules. Sesuai dengan FIBA Rules peraturan bolabasket terdiri dari 8 (delapan ) peraturan dengan 50 (limapuluh) pasal, serta dengan 52 (lima puluh dua) gerakan sinyal tangan (hand signals) belum termasuk gerakan melaporkan nomor yang dimulai dari angka 0-99 (kosong sampai Sembilan puluh Sembilan), jadi hanya untuk membahas mengenai peraturan saja sudah sangat kompleks dan banyak gerakan serta pemahaman yang harus diketahui.

Waktu jam pelajaran yang terbatas merupakan salah satu masalah lain yng didapati dalam proses penyampaian materi penjasorkes yang memiliki kekhususan teknik, perbedaan gerakan dasar, dan aturan permainan, dalam 1 (satu) minggu penjasorkes di SMA hanya mempunyai 3 (tiga) jam pelajaran dengan berurutan tidak dipisah, 1 (satu) jam pelajaran 45 menit. Sehingga sangat terbatas sekali proses menyampaikan materi dengan benar dan tepat tanpa memakai alat bantu pelajaran/media pembelajaran.

Wawancara awal penulis dengan guru mata pelajaran Penjasorkes SMA di Kabupaten Sleman untuk mata pelajaran bola basket terutama untuk peraturan dan sinyal-sinyal wasit bola basket didapati beberapa kesimpulan awal yaitu sebagai berikut: (1) Belum ada penyampaian materi secara spesifik untuk guru penjas- 
orkes karena keterbatasan alat bantu baik berupa gambar maupun video yang membantu untuk menjelaskan secara rinci sinyal-sinyal wasit dalam olahraga bola basket, (2) latar belakang olahraga guru Penjasorkes yang berbeda-beda dan tidak semua memahami tentang permainan bola basket, (3) belum adanya media pembelajaran yang membantu guru untuk memahami tentang sinyal-sinyal dalam permainan bola basket, (4) keterbatasan waktu dalam mata pelajaran Penjasorkes di sekolahan karena untuk memperlajari bola basket secara detail terutama dalam peraturan permainan dan sinyal sinyal wasit bola basket sangat memakan waktu dan tidak mencukupi jumlah jam pelajaran yang ada, (5) guru yang diwawancara awal menyampaikan menginginkan media pembelajaran sinyal-sinyal wasit berupa video, karena dinilai lebih bisa menjelaskan karena dengan gerakan model di dalam video akan lebih menjelaskan daripada media pembelajaran yang lain, video juga dapat diputar kembali ketika ingin mempelajarinya lagi sebelum menyampaikan materi ke siswa didik dan dapat diputar didepan siswa sebagai salah satu media pembelajaran ke siswa

Sesuai latar belakang masalah yang dikemukakan dan dengan mempertimbangkan luasnya cakupan permasalahan yang ada, maka penelitian ini dibatasi pada pengembangan video pembelajaran sinyal-sinyal wasit bola basket untuk guru Penjasorkes yang praktis dan mudah digunakan.

Rumusan masalah dalam penelitian ini sebagai berikut: (1) Bagaimana mengembangkan produk video pembelajaran sinyal-sinyal perwasitan bola basket untuk guru Penjasorkes SMA yang mudah dipahami dan dapat meningkatkan pengetahuan guru Penjasorkes SMA tentang perwasitan bola basket?, (2) Bagaimana kelayakan video pembelajaran sinyal-sinyal perwasitan bola basket sesuai dengan peraturan FIBA 2014? (3) Bagaimana efektifitas dari pengembangan video pembelajaran sinyal-sinyal wasit bola basket untuk guru Penjasorkes SMA?

Penelitian ini berasumsi bahwa guru mata pelajaran pendidikan jasmani kesehatan dan olahraga adalah tenaga pendidikan yang memberikan pelajaran pendidikan jasmani dan olahraga di sekolah. Guru dituntut untuk mengetahui dan bisa menerangkan tentang berbagai macam olahraga baik olahraga individu, maupun olahraga beregu/ berkelompok yang diajarkan sesuai dengan silabus pada kurikulum yang berlaku dengan keterbatasan waktu dan jam pelajaran di sekolah. Salah satu olahraga yang diajarkan adalah bola basket.

Bola basket adalah salah satu permainan beregu yang mempunyai teknik dasar dan peraturan yang banyak dan setiap gerakan mempunyai nama dan penjelasan masing-masing, dalam permainan bola basket memiliki aturan permainan yang sangat banyak dan kompleks, sehingga bagi guru diperlukan pengetahuan dan pemahaman peraturan dasar perwasitan bola basket, karena pada waktu mengajar, mewasiti pertandingan ketika mata pelajaran bola basket dan, memberikan penilaian dengan benar dan sesuai dengan aturan yang berlaku.

Keterbatasan dalam penelitian ini adalah subjek penelitian hanya dalam lingkup guru SMA Penjasorkes Kabupaten Sleman, masih banyak tempat lain yang belum diteliti karena keterbatasan waktu, tenaga, biaya, dan luasnya wilayah penelitian, sehingga penulis hanya bisa mengembangkan di wilayah Kabupaten Sleman Daerah Istimewa Yogyakarta. Keterbatasan pengembangan video ini hanya mencakup pada sinyal-sinyal wasit bola basket, sedangkan untuk materi lain dalam bola basket atau olahraga lain belum dikembangkan. Peneliti melakukan penelitian ini memiliki tujuan untuk mengembangkan video pembelajaran sinyal-sinyal wasit sesuai dengan FIBA rules 2014 untuk Guru Penjasorkes SMA

\section{METODE}

Penelitian ini merupakan jenis penelitian pengembangan (Research and Development). Penelitian ini bertujuan menghasilkan produk video pembelajaran sinyal-sinyal wasit bola basket untuk guru Penjasorkes Sekolah Menengah Atas. Penelitian dan pengembangan (Research and Development) yaitu jenis penelitian yang digunakan untuk menghasilkan produk tertentu, dan menguji keefektifan produk tersebut supaya dapat berfungsi di masyarakat luas, (Sugiyono, 2012, p.297).

Tujuan dari penelitian dan pengembangan yang dilakukan dalam penelitian ini yaitu untuk menghasilkan video pembelajaran sinyal-sinyal wasit bola basket untuk guru Penjasorkes SMA sesuai dengan FIBA Rule 2014. Subjek penelitian ini adalah guru SMA Negeri di Kabupaten Sleman yang berjumlah 33 guru, dengan pembagian sebagai berikut: subjek uji coba produk terdiri dari 6 (enam) guru Penjasorkes SMA negeri di Kabupaten Sleman, subjek uji coba pemakaian berjumlah 27 guru. Penelitian dan Pengembangan ini dilakukan mulai bulan Juli 
sampai dengan September tahun 2016. Tempat Penelitiannya adalah SMA Negeri se-Kabupaten Sleman yang berjumlah 17 Sekolahan,

Prosedur penelitian dan pengembangan ini mengacu pada langkah yang dikembangkan oleh Sugiyono. yang meliputi: (1) potensi dan masalah, (2) pengumpulan data, (3) desain produk, (4) validasi desain, (5) revisi desain, (6) ujicoba produk, (7) revisi produk, (8) ujicoba pemakaian, (9) revisi produk, dan (10) produksi masal.

Jam pelajaran yang terbatas merupakan salah satu masalah yang didapati dalam proses penyampaian materi penjasorkes dalam 1 (satu) minggu penjasorkes di SMA hanya mempunyai 3 (tiga) jam pelajaran dengan berurutan tidak dipisah, 1 (satu) jam pelajaran 45 menit, sehingga sangat terbatas sekali proses menyampaikan materi dengan benar dan tepat tanpa memakai alat bantu pelajaran/media pembelajaran. Perbedaan kompetensi, latar belakang dan keterampilan seorang guru dalam menyampaikan materi pembelajaran bisa menjadikan salah satu hambatan dalam penyampaian materi.

\section{Pengumpulan Data}

Hasil wawancara awal didapatkan bahwa guru penjasorkes SMA Negeri dikabupaten Sleman berjumlah 33 orang, dari 33 orang guru yang memiliki dasaran/basic pemain, pelatih, wasit, pengawas pertandingan dalam olahraga Bola basket hanya 3 orang, atau hanya 9\%, sedangkan yang terbanyak sepakbola 13 orang $(42 \%)$ diikuti bola voli 8 orang $(30 \%)$, senam 3 (9\%), bulu tangkis $6(18 \%)$.

Wawancara 3 guru yang ditemui di sekolah masing masing didapatkan kesimpulan bahwa rata-rata dalam olahraga permainan bola basket di sekolah belum dilakukan simulasi perwasitan, sehingga ketika jam olahraga dan materi permainan bola basket cenderung hanya bermain permainan bola basket tanpa memakai aturan dari FIBA atau federasi bola basket internasional.

\section{Desain Produk}

Dari hasil pengumpulan data di atas peneliti kemudian melakukan desain produk yang akan dikembangkan yaitu video pembelajaraan sinyal-sinyal wasit bola basket, mengacu dari FIBA rules/ peraturan FIBA yang terbaru yaitu tahun 2014 pembuatan materi sinyal-sinyal wasit yang ada di FIBA rules/aturan FIBA dijabarkan dalam bentuk video dan narasi, sehingga diharapkan bisa mempermudah guru penjasor- kes dalam mengetahui dan memahami sinyalsinyal wasit dalam olahraga bola basket.

Setelah materi disiapkan dan dibahas dengan model yaitu Sedyo Mukti Wibowo, S. Psi (Model adalah wasit bola basket berlisensi Internasional/FIBA berasal dari DIY), pengambilan video dilakukan pada tanggal 16 Februari 2016 jam 11.00 WIB - 13.00 WIB.

\section{Validasi Desain}

Setelah proses editing selesai dan sudah menjadi produk awal, dilanjutkan dengan melakukan validasi ahli yang bertujuan untuk mendapatkan penilaian layak atau tidak video ini dikembangkan dan juga untuk mendapatkan saran dan masukan agar produk yang dikembangkan dapat menjadi lebih baik. Dalam penelitian ini menggunakan 2 validasi ahli yaitu ahli media dan ahli materi

Validasi ahli media yang menjadi validator dalam penelitian ini adalah beliau Prof. Herman Dwi Surjono, Ph.D. beliau adalah dosen pascasarjana UNY, Kaprodi jurusan Teknologi Pembelajaran Pascasarjana UNY. Validasi dengan Ahli media dilakukan pada tanggal 29 Maret 2016.

Ahli materi yang menjadi validator dalam penelitian ini adalah beliau Ilham Burhannudin, S. E, beliau adalah salah satu wasit bola basket dari Pengprov D.K.I Jakarta yang berlisensi internasional/FIBA. Mempunyai lisensi internasional sejak tahun 2012 beliau mempunyai pengalaman memimpin pertandingan internasional (SEA Games, SEABA, FIBA ASIA KU 16), dan menjadi wasit dalam kompetisi bola basket profesional Indonesia sampai dengan musim lalu., validasi dilakukan pada tanggal 23 Maret 2016.

\section{Revisi Desain}

Video pembelajaran yang telah dilakukan validasi, kemudian dianalisis dan dilakukan perbaikan sesuai dengan saran dan masukan dari validator.

\section{Uji Coba Produk}

Uji coba produk ini dilakukan terhadap 6 guru Penjasorkes dengan menggunakan angket, dengan melampirkan saran dan masukan.

\section{Revisi Produk}

Produk yang telah diujicoba dianalisis dan direvisi sesuai dengan saran yang dilampirkan oleh guru SMA Negeri di Kabupaten Sleman yang ditunjuk menjadi observer diujicoba. 


\section{Uji Coba Pemakaian}

Produk video yang telah direvisi berdasarkan saran pada ujicoba dilanjutkan dengan melakukan uji coba pemakaian, ujicoba pemakaian dilakukan pada 27 guru penjasorkes SMA Negeri di Kabupaten Sleman dengan menggunakan angket, dengan melampirkan saran dan masukan.

\section{Revisi Produk}

Produk yang telah diuji coba pemakaian dianalisis dan direvisi sesuai dengan saran dan masukan.

\section{Produksi Masal}

Setelah melalui berbagai proses revisi maka dilakukan penyusunan dan pembuatan produk akhir atau produk final berupa video pembelajaran dalam bentuk VCD

\section{Desain Uji Coba}

A test-retest stability coefficient measures the consistency of test results if the same test could be given to the same population again under identical circumstances (Adams \& Wieman, 2010, p.16). Sebuah koefisien stabilitas tes-tes ulang mengukur konsistensi hasil tes jika pengujian yang sama dapat diberikan kepada populasi yang sama lagi dalam keadaan yang identik.

Dalam penelitian ini uji efektifitas produk pada pengembangan video pembelajaran sinyalsinyal wasit bolabasket untuk guru Penjasorkes SMA dilakukan dengan cara mendatangi satu persatu sekolah yang sudah ditentukan sebagai objek coba. Uji coba dilakukan dengan melakukan tes awal (pre-test) dengan menggunakan kuesioner pilihan ganda sejumlah 20 soal untuk mengetahui pengetahuan dasar guru-guru penjasorkes SMA tentang bolabasket, setelah itu kemudian diberikan CD video pembelajaran sinyal-sinyal wasit bola basket untuk guru penjasorkes SMA untuk dipelajari.

Tujuan uji efektifitas adalah untuk mengetahui apakah video pembelajaran yang dibuat dapat meningkatkan pengetahuan guru Penjasorkes SMA mengenai sinyal-sinyal perwasitan bola basket, dan untuk mengetahui kendala dan hambatan yang terjadi untuk pengembangan produk video ini.

\section{Teknik dan Instrumen}

Pengumpulan Data Teknik analisis data yang digunakan dalam penelitian pengembangan ini adalah teknik analisis kualitatif dan kuan- titatif. Teknik analisis kualitatif bersifat induktif yaitu suatu analisis yang diperoleh berdasarkan hasil data yang terkumpul. Sedangkan teknik analisis kuantitatif bersifat deskriptif berupa persentase. Hasil analisis data ini akan menjadi dasar dalam penyempurnaan penelitian pengembangan ini.

Instrumen yang digunakan untuk mengumpulkan data adalah berbentuk angket. Angket digunakan untuk mengumpulkan data dari ahli dan guru penjasorkes. Alasan memilih angket karena subjek relatif banyak sehingga dilakukan secara serentak dan waktu yang singkat. Ahli dan guru penjasorkes diberikan angket penilaian yang berbeda.

Penilaian ahli dititikberatkan kepada produk kualitas media dan kualitas materi yang dibuat, sedangkan penilaian untuk guru penjasorkes dititikberatkan pada kenyamanan pada penggunaan produk, yaitu dalam video pembelajaran yang dikembangkan. Angket penilaian yang digunakan untuk ahli berupa sejumlah aspek yang harus dinilai kelayakannya.Faktor yang digunakan dalam penilaian berupa kualitas video, kesesuaian materi, ketepatan gerakan dari video yang dikembangkan. Angket yang disusun meliputi tiga jenis sesuai peran dan posisi responden dalam pengembangan ini, angket tersebut meliputi: (1) Angket untuk ahli materi, (2) angket untuk ahli media, (3). Angket untuk guru penjasorkes, (4) Kuisioner untuk Uji Efektifitas/Uji operasional

Instrumen pengumpulan data yang pertama disebarkan kepada para ahli untuk divalidasi.Instrumen pengumpulan data validasi pada penelitian ini adalah angket berupa skor penilaian dan tanggapan dari validator yang digunakan untuk menentukan validitas perangkat penilaian yang dikembangkan.

Berikut ini adalah kisi-kisi instrumen yang digunakan untuk menilai perangkat penilaian yang dikembangkan.

\section{Kisi-kisi Angket untuk Ahli Media}

Instrumen yang digunakan ahli media ditinjau dari aspek kualitas video, dengan 4 indikator dan 10 butir soal. Kisi-kisi instrumen untuk ahli materi dapat disajikan pada Tabel 1.

Tabel 1. Kisi-Kisi Instrumen untuk Ahli Media

\begin{tabular}{cl}
\hline Aspek & \multicolumn{1}{c}{ Indikator } \\
\hline \multirow{2}{*}{ Kualitas } & a. Kualitas video \\
Video & b. Ketepatan narasi \\
& c. Ketepatan pemakaian huruf \\
& d. Keterbacan tulisan \\
\hline
\end{tabular}


Kisi-kisi Angket untuk Ahli Materi

Instrumen yang digunakan ahli materi ditinjau dari aspek kualitas materi dengan 4 indikator di dalamnya serta 11 butir soal. Kisi-kisi instrumen untuk ahli materi dapat disajikan pada Tabel 2.

Tabel 2. Kisi-Kisi Instrumen Uji Kelayakan untuk Ahli Materi

\begin{tabular}{cl}
\hline Aspek & \multicolumn{1}{c}{ Indikator } \\
\hline \multicolumn{3}{c}{ a. Kesesuaian dengan Peraturan } \\
Kualitas & \multicolumn{1}{c}{ FIBA } \\
materi & b. Kesesuaian gerakan \\
& c. Kesesuaian narasi \\
& d. Kejelasan petunjuk di dalam video \\
\hline
\end{tabular}

Kisi-kisi Angket untuk Guru Penjasorkes

Instrumen yang digunakan ahli materi ditinjau dari aspek kualitas materi dan kualitas video dengan 8 indikator di dalamnya serta 19 butir soal. Kisi-kisi angket untuk guru penjasorkes dapat disajikan pada Tabel 3.

Tabel 3. Kisi-Kisi Angket untuk guru Penjasorkes

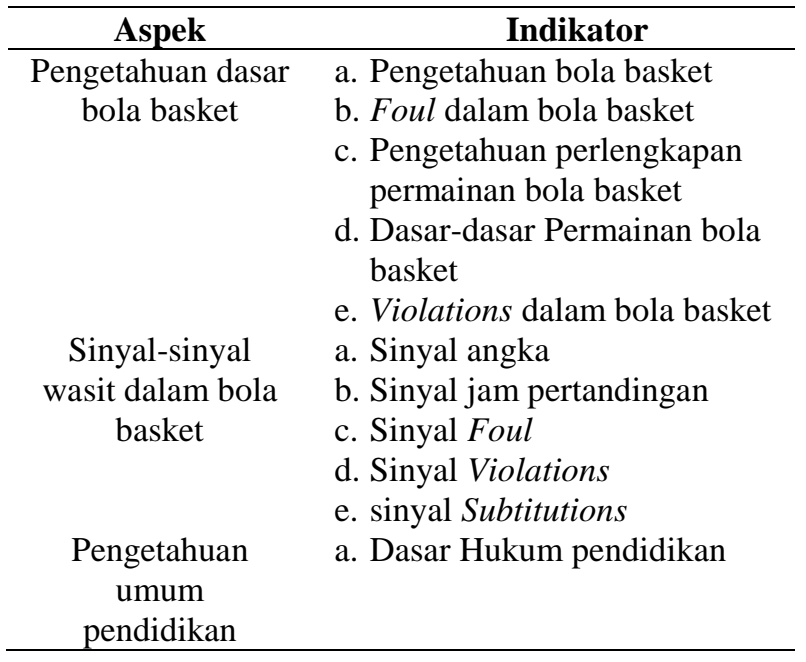

Kisi-kisi Uji Coba Instrumen

Instrumen yang digunakan untuk uji ini adalah mahasiswa PJKR UNY yang telah melakukan Praktek Pengajaran Lapangan (PPL) di SMA, berjumlah 10 orang dengan memilih secara acak, berjumlah 30 soal dengan bentuk pilihan ganda.Kisi-kisi uji efektifitas disajikan dalam Tabel 4.

Untuk mengetahui apakah item yang disusun itu merupakan instrumen yang valid dan reliabel maka diperlukan uji coba instrumen tersebut. Valid dan sahih tidaknya instrumen akan mempengaruhi benar tidaknya data yang diperoleh, maka uji coba instrumen ini dimak- sudkan untuk mengetahui validitas dan reliabilitas, sehingga instrumen yang sudah teruji validitas dan reliabilitasnya baru dapat digunakan.

Tabel 4. Kisi-Kisi Ujicoba instrumen

\begin{tabular}{|c|c|}
\hline Aspek & Indikator \\
\hline $\begin{array}{c}\text { Pengetahuan dasar } \\
\text { bola basket }\end{array}$ & $\begin{array}{l}\text { a. Pengetahuan bola basket } \\
\text { b. Foul dalam bola basket } \\
\text { c. Pengetahuan perlengkapan } \\
\text { permainan bola basket } \\
\text { d. Dasar-dasar permainan bola } \\
\text { basket } \\
\text { e. Violations dalam bola basket }\end{array}$ \\
\hline $\begin{array}{c}\text { Sinyal-sinyal } \\
\text { wasit dalam bola } \\
\text { basket }\end{array}$ & $\begin{array}{l}\text { f. Sinyal angka } \\
\text { g. Sinyal jam pertandingan } \\
\text { h. Sinyal Foul } \\
\text { i. Sinyal Violations } \\
\text { j. Sinyal Subtitutions }\end{array}$ \\
\hline $\begin{array}{c}\text { Pengetahuan } \\
\text { umum Pendidikan }\end{array}$ & b. Dasar hukum pendidikan \\
\hline
\end{tabular}

Uji coba instrumen dalam penelitian ini mengambil beberapa mahasiswa PJKR UNY yang telah melakukan Praktek Pengajaran Lapangan (PPL) di SMA yang telah melakukan KBM sehingga diharapkan mempunyai kesamaan dengan objek coba, yaitu guru penjasorkes yang nantinya dijadikan sampel, untuk ujicoba dilakukan tanggal 25-26 Juli 2016 dengan memberikan angket uji instrumen yang akan diisi oleh 10 orang responden secara tertutup. Pengujian Validitas dan Reliabilitas menggunakan bantuan software SPSS ( Statistic Package and Social Science) 16.0 for window

\section{Uji Validitas}

Rumus korelasi yang dapat digunakan adalah yang sering dikenal dengan rumus korelasi product moment sebagai berikut:

$$
r_{x y}=\frac{n \sum X Y-\left(\sum X\right)\left(\sum Y\right)}{\sqrt{\left\{n X^{2}-\left(\sum X\right)^{2}\right),\left\{\sum Y^{2}-\left(\sum Y\right)^{2}\right\}}}
$$

Keterangan:

$\mathrm{r}_{\mathrm{xy}} \quad$ : Koefisien validitas

$n \quad:$ Jumlah subjek

$\sum \mathrm{X}:$ Jumlah skor item

$\sum Y$ : Jumlah skor total

$\sum X Y$ : Jumlah hasil kali skor item dengan skor total

$\sum \mathrm{X}^{2}$ : Jumlah kuadrat skor item

$\sum \mathrm{Y}^{2}:$ Jumlah kuadrat skor total

Arikunto (2013, p.170)

Hasil analisis validitas atau kesahihan instrumen dilakukan dengan membandingkan antara nilai corrected item- total correlation hasil perhitungan dengan taraf signifikansi $5 \%$ 
maka angka yang diperoleh 0,632. Hasil uji validitas terdapat dibawah ini.Dari 30 butir pertanyaan, setelah dilakukan ujicoba penelitian terdapat 10 butir pertanyaan yang gugur, yaitu butir nomor $(4,5,9,13,14,15,18,21,24,28)$ dengan 20 butir pernyataan valid.

\section{Hasil Uji Reliabilitas}

Sugiyono (2010, p.3), menguji reliabilitas instrumen, Syarat keterandalan suatu instrumen menuntut kemantapan dan keajegan hasil pengamatan dengan instrumen (pengukuran) apapun yang diamati dalam keadaan tidak berubah dalam kurun waktuamatan pertama sampai amatan selanjutnya.Analisis keandalan butir hanya dilakukan pada butir-butir yang sahih saja, bukan pada semua butir yang belum diuji kesahihannya.

Instrumen dikatakan reliabel apabila instrumen tersebut mampu mengungkapkan data yang bisa dipercaya dan sesuai dengan kenyataan yang sebenarnya. Perhitungan reliabilitas menggunakan rumus Alpha Cronbach sebagai berikut:

$\mathbf{r}_{11}=\left[\frac{k}{(k-1)}\right]\left[1-\frac{\sum \delta_{b}^{2}}{\delta_{b}^{2}}\right]$

Keterangan:

$\mathrm{r}_{11}$ : Reliabilitas instrumen

$\mathrm{k}$ : Banyaknya butir pernyataan atau pertanyaan

$\sum \delta_{b}^{2}:$ Jumlah varians butir

$\delta_{b}^{2}$ : Varians total

Arikunto, (2013, p.196)

Sebagai tolak ukur tinggi rendahnya koefisien reliabilitas digunakan interprestasi yang dikemukakan oleh Arikunto (2013, p. 233) sebagai berikut:

$0,800-1,00=$ Sangat tinggi

$0,600-0,800=$ Tinggi

$0,400-0,600=$ Cukup

$0,200-0,400=$ Rendah

$0,00-0,200=$ Sangat rendah

Berdasarkan hasil perhitungan reliabilitas menggunakan teknik Alpha Cronbach melalui program SPSS seri 16.0 reliabilitas diperoleh koefisien Alpha pada kuesioner sebesar 0,991 dan masuk dalam interprestasi sangat tinggi. Dapat disimpulkan bahwa kuesioner dalam penelitian ini adalah reliabel sehingga layak digunakan untuk pengambilan data penelitian.
Data dari hasil penilaian menggunakan instrumen ini digunakan untuk menganalisis instrumen. Suatu alat penilaian dikatakan mempunyai kualitas yang reliabilitas perangkat penilaian yang digunakan.

\section{Teknik Analisis Data}

Teknik analisis data yang digunakan dalam penelitia pengembangan ini adalah menggunakan teknik analisis deskriptif yang dituangkan dalam bentuk persentase, sedangkan data yang berupa saran dan alasan memilih jawaban dianalisis menggunakan analisis kualitatif. Adapun rumus yang digunakan dalam penelitian pengembangan ini adalah sebagai berikut:

$\mathrm{P}=\frac{F}{N} X 100 \%$

Keterangan:

$\mathrm{P}=$ Persentase yang dicari (Frekuensi Relatif)

$\mathrm{F}=$ Frekuensi

$\mathrm{N}=$ Jumlah Responden

Dari hasil persentase yang diperoleh kemudian diklasifikasikan untuk memperoleh kesimpulan data, selengkapnya disajikan pada Tabel 5.

Tabel 5. Norma Penilaian

\begin{tabular}{cc}
\hline Norma & Kategori \\
\hline $\mathrm{X}>\mathrm{Mi}+1,8 \mathrm{SBi}$ & Sangat Tinggi \\
$\mathrm{Mi}+0,6 \mathrm{SBi}<\mathrm{X}<\mathrm{Mi}+1,8 \mathrm{SBi}$ & Tinggi \\
$\mathrm{Mi}-0,6 \mathrm{SBi}<\mathrm{X}<\mathrm{Mi}+0,6 \mathrm{SBi}$ & Sedang \\
$\mathrm{Mi}-1,8 \mathrm{SBi}<\mathrm{X}<\mathrm{Mi}-0,6 \mathrm{SBi}$ & Rendah \\
$X<M i-1,8 \mathrm{SBi}$ & Sangat Rendah \\
\hline
\end{tabular}

Keterangan:

$X=$ Skor akhir

$\mathrm{Mi}=$ Mean ideal

$\mathrm{SBi}=$ Simpangan baku ideal

Rumus Mi $=1 / 2$ (skor tertinggi ideal + skor terendah ideal

Rumus SBi = (1/2) (1/3) (skor maksimal ideal skor minimal ideal)

Skor tertinggi ideal $=\Sigma$ butir kriteria $\mathrm{x}$ skor tertinggi

Skor terendah ideal $=\Sigma$ butir kriteria $\mathrm{x}$ skor terendah

\section{HASIL DAN PEMBAHASAN}

\section{Data Validasi}

Validasi dengan ahli media dilakukan pada tanggal 29 Maret 2016. Dari data hasil validasi dari ahli media didapatkan data pada Tabel 6. 
Jurnal Keolahragaan 6 (1), 2018 - 55

Duwi Kurnianto Pambudi, S. Suharjana

Tabel 6. Norma Penilaian Validasi Ahli Media

\begin{tabular}{cccc}
\hline Nilai yang didapat $(\mathbf{F})$ & Nilai maksimal $(\mathbf{N})$ & Hasil $(\mathbf{P})$ & Kategori \\
\hline 38 & 45 & $84,44 \%$ & Sangat Tinggi \\
\hline
\end{tabular}

Tabel 7. Norma Penilaian Validasi Ahli Materi

\begin{tabular}{cccc}
\hline Nilai yang didapat $(\mathbf{F})$ & Nilai maksimal $(\mathbf{N})$ & Hasil $(\mathbf{P})$ & Kategori \\
\hline 51 & 55 & $92,72 \%$ & Sangat Tinggi \\
\hline
\end{tabular}

Tabel 8. Norma Penilaian Validasi Ahli

\begin{tabular}{cccc}
\hline Nilai validasi Ahli Media & Nilai validasi Ahli Materi & Hasil (P) & Kategori \\
\hline $84,44 \%$ & $92,72 \%$ & $88,58 \%$ & Sangat Tinggi \\
\hline
\end{tabular}

Tabel 9. Norma Penilaian Uji Coba Produk

\begin{tabular}{ccccc}
\hline Nama & Nilai yang didapat $(\mathbf{F})$ & Nilai maksimal $(\mathbf{N})$ & Hasil $(\mathbf{P})$ & Kategori \\
\hline Sami & 90 & 95 & $92,72 \%$ & Sangat Tinggi \\
Arum & 88 & 95 & $92,63 \%$ & Sangat Tinggi \\
Gunawan & 87 & 95 & $91,57 \%$ & Sangat Tinggi \\
Adip & 89 & 95 & $93,68 \%$ & Sangat Tinggi \\
Karmanto & 90 & 95 & $92,72 \%$ & Sangat Tinggi \\
Lukas & 88 & 95 & $92,63 \%$ & Sangat Tinggi \\
Jumlah & 532 & 570 & 93,33 & Sangat Tinggi \\
\hline
\end{tabular}

Data yang didapatkan dari hasil validasi ahli adalah masuk dalam kategori Sangat tinggi dengan hasil $84,44 \%$. Saran dan masukan untuk produk video dari validator ahli media ditindak lanjuti dengan melakukan revisi sesuai saran dan masukan.

\section{Validasi Ahli Materi}

Ahli materi yang menjadi validator dalam penelitian ini adalah beliau Ilham Burhannudin, S. E, beliau adalah salah satu wasit bola basket dari Pengprov D.K.I Jakarta yang berlisensi internasional/FIBA. Mempunyai lisensi internasional sejak tahun 2012 beliau mempunyai pengalaman memimpin pertandingan internasional (SEA Games, SEABA, FIBA ASIA KU 16), dan menjadi wasit dalam kompetisi bola basket profesional Indonesia sampai dengan musim lalu., validasi dilakukan pada tanggal 23 Maret 2016.

Dari data yang diperoleh dari Ahli materi, kemudian dilanjutkan dengan melakukan analisis untuk mendapatkan hasil, hasil validasi dari ahli materi didapatkan data pada Tabel 7.

Data yang didapatkan dari hasil validasi ahli adalah masuk dalam kategori Sangat tinggi dengan hasil 92,72 \%. Hasil validasi dari Ahli media dan ahli materi setelah dianalisis mendapatkan data pada Tabel 8.

Data yang didapatkan dari hasil validasi ahli adalah masuk kedalam kategori Sangat tinggi dengan hasil $88,58 \%$, sehingga dari hasil validasi tersebut, maka video pembelajaran sinyal- sinyal wasit bola basket untuk guru penjasorkes SMA layak dan dapat dilanjutkan untuk dilakukan ujicoba produk.

Hasil Uji Coba Produk.

Video pengembangan sinyal-sinyal wasit hasil revisi dari saran dan masukan ketika validasi ahli media dan ahli materi kemudian dilanjutkan untuk melakukan uji coba produk. Uji coba produk dalam penelitian ini dilakukan 2 kali, yaitu uji coba produk dengan 6 guru, dan ujicoba pemakaian dengan 27 guru penjasorkes SMA Negeri di Kabupaten Sleman melakukan penilaian dengan angket sesuai dengan kisi-kisi yang telah disiapkan

Ujicoba Produk

Ujicoba produk dilakukan dengan cara mendatangi kesekolahan yang telah di tentukan untuk guru penjasorkes sebagai subjek, pelaksanaan uji coba produk dilaksanakan tanggal 1 Agustus sampai dengan 3 Agustus 2016.

Dari data yang diperoleh dari uji coba produk, kemudian dilanjutkan dengan melakukan analisis untuk mendapatkan hasil, hasil ujicoba produk didapatkan data pada Tabel 9.

Data yang didapatkan dari hasil uji coba produk masuk dalam kategori Sangat tinggi dengan rata-rata $93,33 \%$.

\section{Uji Coba Pemakaian}

Uji coba pemakaian dilakukan setelah uji coba produk selesai dan video yang diberikan ke 
guru penjasorkes direvisi sesuai dengan saran dan masukan dari uji coba produk. Uji coba pemakaian dilakukan pada saat Musyawarah Guru Mata Pelajaran (MGMP) Penjasorkes SMA se Kabupaten Sleman pada tanggal 8 Agustus 2016 di R.M Muara Kapuas Ngaglik Sleman Yogyakarta, untuk guru yang tidak hadir di MGMP ujicoba pemakaian dilakukan dengan cara mendatangi kesekolahan masing-masing, pelaksanaan uji pemakaian susulan pada tanggal 9 Agustus sampai dengan 11 Agustus 2016, dari uji coba pemakaian didapatkan data pada Tabel 10.

Data yang didapatkan dari hasil ujicoba pemakaian, produk yang dikembangkan masuk dalam kategori Sangat tinggi, dengan rata-rata 92,59\%. Saran dan masukan untuk produk video dari guru penjasorkes yang menjadi subjek uji coba produk ditindak lanjuti dengan melakukan revisi sesuai saran dan masukan

\section{Uji Efektifitas/Uji Operasional}

Dalam uji efektifitas ini peneliti melakukan 2 kali tes, yaitu pre-test dan post-test. Pengambilan data pre-test dilakukan pada tanggal 30 juli 2016, 1-2 Agustus 2016, dengan memberikan soal tes yang sudah dilakukan uji validasi dan reliabilitas sejumlah 20 butir soal pilihan ganda, dikerjakan secara langsung pada saat dibagikan, post-test dilakukan pada tanggal 10, 11, 12 November 2016, post-test dilakukan setelah guru penjasorkes SMA mempelajari video pembelajaran sinyal-sinyal wasit bola basket yang telah diberikan setelah pre test dilakukan. Hasil uji efektifitas dapat disajikan dalam Tabel 11.

Tabel 10. Norma Penilaian Ujicoba Pemakaian

\begin{tabular}{lcccc}
\hline \multicolumn{1}{c}{ Nama } & Nilai yang didapat (F) & Nilai maksimal (N) & Hasil (P) & Kategori \\
\hline Handaka & 88 & 95 & $92,63 \%$ & Sangat Tinggi \\
Imam & 90 & 95 & $94,73 \%$ & Sangat Tinggi \\
Mariyem & 89 & 95 & $93,68 \%$ & Sangat Tinggi \\
Muhammad & 89 & 95 & $93,68 \%$ & Sangat Tinggi \\
Rina & 85 & 95 & $89,47 \%$ & Sangat Tinggi \\
Arif & 88 & 95 & $92,63 \%$ & Sangat Tinggi \\
Bambang & 90 & 95 & $94,63 \%$ & Sangat Tinggi \\
Sunaryo & 91 & 95 & $95,78 \%$ & Sangat Tinggi \\
Sumarjo & 88 & 95 & $92,63 \%$ & Sangat Tinggi \\
Purgiyanto & 86 & 95 & $90,52 \%$ & Sangat Tinggi \\
Setyotomo & 85 & 95 & $89,47 \%$ & Sangat Tinggi \\
Lasianus & 90 & 95 & $94,63 \%$ & Sangat Tinggi \\
Agung & 88 & 95 & $92,63 \%$ & Sangat Tinggi \\
Iswanto & 84 & 95 & $88,42 \%$ & Sangat Tinggi \\
Katarina & 88 & 95 & $92,63 \%$ & Sangat Tinggi \\
Kliwon & 84 & 95 & $88,42 \%$ & Sangat Tinggi \\
Agus & 90 & 95 & $94,73 \%$ & Sangat Tinggi \\
Darwito & 88 & 95 & $92,63 \%$ & Sangat Tinggi \\
Irfan & 88 & 95 & $92,63 \%$ & Sangat Tinggi \\
Tio & 89 & 95 & $93,68 \%$ & Sangat Tinggi \\
Rahmat & 90 & 95 & $94,73 \%$ & Sangat Tinggi \\
Fajar & 89 & 95 & $93,68 \%$ & Sangat Tinggi \\
Hernawan & 86 & 95 & $90,52 \%$ & Sangat Tinggi \\
Ayu & 90 & 95 & $94,73 \%$ & Sangat Tinggi \\
Yanuar & 89 & 95 & $93,68 \%$ & Sangat Tinggi \\
Hilda & 85 & 95 & $89,47 \%$ & Sangat Tinggi \\
Putri & 88 & 95 & $92,63 \%$ & Sangat Tinggi \\
Jumlah & 2375 & $965 \%$ & Sangat Tinggi \\
\hline
\end{tabular}


Jurnal Keolahragaan 6 (1), 2018 - 57

Duwi Kurnianto Pambudi, S. Suharjana

Tabel 11. Hasil Uji Efektifitas/Uji Operasional

\begin{tabular}{|c|c|c|c|}
\hline Nama & Hasil Pretest & Hasil Postest & Keterangan \\
\hline Handaka & 9.5 & 10 & Naik 0.5 poin \\
\hline Imam & 7.5 & 8.5 & Naik 1 poin \\
\hline Mariyem & 8.5 & 9 & Naik 0,5 poin \\
\hline Muhammad & 8.5 & 9 & Naik 0.5 poin \\
\hline Rina & 7.5 & 8.5 & Naik 1 poin \\
\hline Arif & 6.5 & 7.5 & Naik 1 poin \\
\hline Bambang & 7.5 & 8 & Naik 0.5 poin \\
\hline Sunaryo & 6.5 & 7.5 & Naik 1 poin \\
\hline Sumarjo & 5 & 6.5 & Naik 1,5 poin \\
\hline Purgiyanto & 6 & 7 & Naik 1 poin \\
\hline Karyawan & 7.5 & 8 & Naik 0.5 poin \\
\hline Lasianus & 9 & 9,5 & Naik 0.5 poin \\
\hline Agung & 5 & 7 & Naik 2 poin \\
\hline Iswanto & 7 & 7.5 & Naik 0.5 poin \\
\hline Katarina & 7.5 & 8.5 & Naik 1 poin \\
\hline Kliwon & 6.5 & 8.5 & Naik 2 poin \\
\hline Agus & 8.5 & 9 & Naik 0.5 poin \\
\hline Darwito & 8.5 & 9.5 & Naik 1 poin \\
\hline Irfan & 8 & 9 & Naik 1 poin \\
\hline Tio & 8.5 & 9 & Naik 0.5 poin \\
\hline Rahmat & 9 & 10 & Naik 1 poin \\
\hline Fajar & 8.5 & 9 & Naik 0.5 poin \\
\hline Hernawan & 6.5 & 7.5 & Naik 1 poin \\
\hline Ayu & 9.5 & 10 & Naik 0.5 poin \\
\hline Yanuar & 6 & 7.5 & Naik 1.5 poin \\
\hline Hilda & 8 & 9 & Naik 1 poin \\
\hline Putri & 5.5 & 7.5 & Naik 2 poin \\
\hline Sami & 8.5 & 9 & Naik 0,5 poin \\
\hline Arum & 6.5 & 7.5 & Naik 1 poin \\
\hline Gunawan & 7 & 8 & Naik 1 poin \\
\hline Adip & 8 & 8.5 & Naik 0.5 poin \\
\hline Karmanto & 6 & 7 & Naik 1 poin \\
\hline Lukas & 7 & 7.5 & Naik 0.5 poin \\
\hline Total Nilai & 245 & 275 & Naik 30 poin \\
\hline Rata-rata & 7.424 & 8.333 & Naik 0.909 poin \\
\hline Rata-rata $(\%)$ & $74,24 \%$ & $83,33 \%$ & Naik $9.09 \%$ \\
\hline
\end{tabular}

Dari data pretest dan Post-test pada uji efektifitas/uji operasional terlihat ada peningkatan rata-rata nilai sebesar $9,09 \%$ yaitu dari $74,24 \%$ pada saat pretest menjadi $88,33 \%$ pada saat post-test.

Produk akhir dalam penelitian pengembangan ini adalah berupa video pembelajaran sinyal-sinyal wasit bola basket yang mengalami beberapa tahapan uji, tahapan-tahapan uji tersebut diantaranya: (1)validasi ahli media, validasi ahli materi, hasil dari validasi dilanjutkan dengan melakukan revisi sesuai dengan saran dan masukan dari validator ahli materi dan ahli media, (2) Uji coba Produk, dengan 6 guru penjasorkes, dilanjutkan dengan revisi sesuai dengan saran dan masukan subjek coba, (3) Uji coba pemakaian, dengan 27 guru Penjasorkes, dilanjutkan dengan revisi sesuai dengan saran dan masukan subjek coba, (4) pembuatan produk final sesuai dengan hasil tahapan ujicoba, diikuti dengan membagikan video yang telah diperbaiki sejumlah 17 , sesuai dengan masing-masing sekolah 1 buah DVD Video Pembelajaran SinyalSinyal Wasit Bola Basket untuk Guru Penjasorkes Sekolah Menengah Atas, (5) Uji Efektifitas/ Uji Operasional.

Hasil dari validasi ahli media menunjukkan nilai $84,44 \%$ dengan kategori sangat tinggi, validasi ahli materi menunjukkan nilai $92,72 \%$, dengan kategori sangat tinggi. Hasil dari validasi menunjukkan nilai $88,58 \%$ dengan kategori sangat tinggi, sehingga video pengembangan sinyal-sinyal wasit bola basket untuk guru penjasorkes SMA layak untuk diujicobakan. Pada uji coba produk hasil penelitian menunjukkan angka 93,33\% dengan kategori sangat tinggi, sehingga dari hasil ujicoba produk menunjukkan video pengembangan sinyal-sinyal wasit untuk 
guru penjasorkes SMA layak diujicoba pemakaian. Hasil dari ujicoba pemakaian menunjukkan angka 92,59\% dengan kategori sangat tinggi.

Dari semua hasil tersebut dapat disimpulkan bahwa video pengembangan sinyal-sinyal wasit bola basket untuk guru penjasorkes SMA mempunyai kategori yang sangat tinggi dan layak untuk digunakan, dengan demikian tahap akhir adalah menyusun video pembelajaran sinyal-sinyal wasit bola basket untuk guru penjasorkes SMA sesuai dengan saran dan masukan, diwujudkan dalam bentuk DVD dengan judul "Video Pembelajaran Sinyal-Sinyal Wasit Bola Basket untuk Guru Penjasorkes Sekolah Menengah Atas". Uji efektifitas/Uji operasional terlihat ada peningkatan rata-rata nilai sebesar 9,09\% yaitu dari $74,24 \%$ pada saat pretest menjadi $83,33 \%$ pada saat post-test.

\section{SIMPULAN DAN SARAN}

\section{Simpulan Produk}

Produk dalam penelitian pengembangan ini adalah berupa DVD yang di dalamya berisi video pembelajaran sinyal-sinyal wasit bola basket sesuai dengan peraturan FIBA tahun 2014 yang bisa dipelajari sebagai sarana pengetahuan dasar perwasitan bola basket untuk guru penjasorkes. Video sinyal-sinyal gerakan wasit terdiri dari: video pengetahuan umum bola basket, ukuran lapangan, perlengkapan dan jumlah wasit dalam pertandingan bola basket, sinyal wasit dalam bolabasket berjumlah 52 gerakan tangan (hands signal) yang di dalamnya dijelaskan dengan narasi yang menjelaskan gerakangerakan sinyal dan gambar di video, cuplikan video yang menjelaskan gerakan sinyal dan contoh video mewasiti pertandingan bola basket yang sesuai dengan materi yang dijelaskan oleh video.

Video pembelajaran ini merangkum dari berbagai materi tentang sinyal-sinyal wasit bola basket, peraturan umum bola basket berserta penjelasan melalui cuplikan video, video pembelajaran berdurasi 24 menit ini dapat menjadi salah satu sumber materi pembelajaran bola basket di SMA pada umumnya dan pada khususnya pada guru penjasorkes dapat meningkatkan pengetahuan dan pemahaman tentang perwasitan bola basket, hal tersebut terlihat dari hasil ujicoba produk dan uji pemakaian yang masuk dalam kategori sangat tinggi dan pada hasil uji efektifitas yang menunjukkan peningkatan.

Hasil dari validasi ahli media menunjukkan nilai $84,44 \%$ dengan kategori sangat tinggi, validasi ahli materi menunjukkan nilai 92,72\%, dengan kategori sangat tinggi. Hasil dari validasi menunjukkan nilai 88,58\% dengan kategori sangat tinggi. Pada ujicoba produk hasil penelitian menunjukkan angka 93,33\% dengan kategori sangat tinggi. Hasil dari uji coba pemakaian menunjukkan angka 92,59\% dengan kategori sangat tinggi.

Dari semua hasil uji produk dan uji pemakaian dapat disimpulkan bahwa video pengembangan sinyal-sinyal wasit bola basket untuk guru penjasorkes SMA mempunyai kategori yang sangat tinggi dan layak untuk digunakan, dengan demikian tahap akhir adalah menyusun video pembelajaran sinyal-sinyal wasit bola basket untuk guru penjasorkes SMA sesuai dengan saran dan masukan, diwujudkan dalam bentuk DVD dengan judul "Video Pembelajaran Sinyal-Sinyal Wasit Bola Basket untuk Guru Penjasorkes Sekolah Menengah Atas".

Uji efektifitas/Uji operasional terlihat ada peningkatan rata-rata nilai sebesar $9,09 \%$ yaitu dari $74,24 \%$ pada saat pretest menjadi $83,33 \%$ pada saat post-test. Dari semua hasil tersebut dapat disimpulkan bahwa video pengembangan sinyal-sinyal wasit bola basket untuk guru penjasorkes SMA mempunyai kategori yang sangat tinggi dan layak untuk digunakan.

\section{Saran Pemanfaatan Produk}

Beberapa saran yang dapat peneliti ajukan untuk memanfaatkan produk video pembelajaran hasil dari penelitian ini antara lain: Dalam mempelajari video pembelajaran sinyal-sinyal wasit diharapkan menambah dengan membaca peraturan bola basket yang dikeluarkan FIBA tahun 2014 dan atau melihat pertandingan bola basket resmi, sehingga dapat dengan lebih cepat memahami gerakan-gerakan sinyal wasit bola basket.

Pengembangan produk lebih lanjut perlu dilakukan penelitian yang melibatkan subjek coba yang lebih besar dan cakupan tempat uji coba yang lebih luas. Di sisi lain, dapat juga dilakukan penelitian serupa pada sasaran subjek yang berbeda.

Pengembangan video pembelajaran sinyal-sinyal wasit bola basket untuk guru penjasorkes SMA dapat dikembangkan lebih lanjut dengan materi yang lebih lengkap.

\section{DAFTAR PUSTAKA}

Adams, W. K., \& Wieman, .C. E. (2010). Development and validation of instrumen to measure learning of expert-like 
Jurnal Keolahragaan 6 (1), 2018 - 59

Duwi Kurnianto Pambudi, S. Suharjana

thingking. International Journal of Science Education, 1-24

Arikunto, S. (2013). Prosedur penelitian; suatu pendekatan praktik.Jakarta: Rineka Cipta

Effendy, F. (2016). Pengembangan multimedia pembelajaran pendidikan jasmani materi permainan sepakbola di SMK Negeri 2 Indramayu. Tesis. Universitas Negeri Yogyakarta

FIBA. (2012). Official basketball rules 2012. Puerto Rico: FIBA.

FIBA. (2014). Official basketball rules 2014. Barcelona: FIBA.
Kusumawardana, D., \& Sukadiyanto, S. (2013). Pengembangan media pembelajaran VCD tenis lapangan bagi siswa sekolah dasar. Jurnal Keolahragaan, 1(2), 120 129.

doi:http://dx.doi.org/10.21831/jk.v1i2.256 8

Sugiyono, S. (2010). Statistika untuk penelitian. Bandung: Alfabeta.

Sugiyono, S. (2012) Metode penelitian pendidikan pendekatan kuantitatif, kualitatif, dan $R \& D$. Bandung: Alfabeta. 